\title{
The Contribution of National Examination Score of Indonesian Language in High School and Reading Strategies toward Students Reading Comprehension Skill in Universitas Negeri Padang
}

\author{
Amril Amir \\ Faculty of Languages and Arts, Universitas Negeri Padang \\ amril.amir23@yahoo.co.id
}

\begin{abstract}
This study was conducted because of the low level of students reading skill. The national examination score Indonesian Languange in high school and reading strategies were assumed as the factors affecting students reading skill. The aim of this study was to describe and to analyze the contribution of national examination score Indonesian Languange in high school and reading strategies toward students' reading comprehension skill. This study used the quantitative method with the descriptive correlational design. The population was 4996 students who attended Bahasa Indonesia subject in Universitas Negeri Padang, and 370 students were taken as samples by using proportional stratified random sampling. The instruments of this study was data reading comprehension test which has been valid and reliable. The result showed that: (1) there was not the contribution of national examination score Indonesian Languange in high school toward students reading comprehension skill; (2) there was the contribution of reading strategies toward students reading comprehension skill; (3) there was the contribution of national examination score Indonesian Languange in high school and reading strategies toward students reading comprehension skill.
\end{abstract}

Keywords- National Examination Score, Indonesia Languange, Reading Strategies and Reading Comprehension Skill.

\section{INTRODUCTION}

Reading comprehension skill is really important for students to obtain information from the books, the magazines, and scientific articles. The information obtained will be useful not only for their future careers (Ahmadi et al., 2013; Papatga \& Ersoy, 2016) but also for their further educations. Reading comprehension is one of the main necessities of students. For example, In the first year of study, reading comprehension is stressed on the explanation of vocabulary in order to help students understand the whole reading passage and will be followed by answering the related questions in spoken or written forms.

The reality is beyond the expectation since most students are unfamiliar with the reading strategy or they do not have any reading skill. The data from Central Bureau of Statistic in 2012 shows that most Indonesians do not prefer to read as informative sources. They tend to prefer television and the radio as the source of information. The tension to get the information from reading has decreased since 2003 to $6.05 \%$ as if it was compared to get information through watching television which gained $6.74 \%$. In 2012 , the data showed that only $17.66 \%$ of Indonesians read while $91.68 \%$ of them watched television and $18.57 \%$ of them listened to the radio. In line with this fact, the finding of Program of International Student Assessment (PISA) team of Ministry of Education in 2011 showed the habit of 15-year-old children in Indonesia (Junior High and Senior High School levels) was very apprehensive. For literal of read, in 2000 Indonesia was in 39th of 41 countries, in 2003 it was in 39th of 40 countries, in 2006 it was in 48th of 56 countries and in 2009 it was in 57 th of 65 countries (PISA, 2015).

Reading comprehension can be divided into four levels: (1) literal, (2) inferential, (3) evaluation and (4) appreciation (Yussof et al., 2013; Ulum, 2016). Literal understanding requires ideas, information, and experiences which are clearly stated in the reading passage. Inferential understanding is needed when the readers use the synthesis of literal content of his selection, personal experience, intuition, and imagination as the basic line of the hypotheses. This understanding comes from the questions which require imagination and thought. Evaluation is shown when the reader review a passage and appreciation, obtained when students can appreciate the reading that has been read. Some factors affecting the problem of students' reading comprehension are the mastery of vocabularies, sentence structures, paragraph structures, and passage, or non-linguistic factors like intelligence, gender, reading interest, reading strategy, and reading frequency (Koda, 2005; Kendou, Mcmaster, \& Christ, 2016; Savage, 2017).

Based on the Circular Letter (SEB) of the Minister of Education and Culture (Mendikbud) and the Minister of Research, Technology and Higher Education (Menristekdikti) Number 0123 / MPK.H / KR / 2015 and Number 8 / M / 
KB / II / 2015 dated February 17 2015, the results of the national examination will be one of the selection considerations in the next education level. The letter was the result of talks with Menristekdikti and Mendikbud. There were three main points in the letter that one of the points was related to the national exam results into one of the selection of admission to State University (PTN) or the level of secondary education junior high or high school.

The students' reading comprehension skills are related to their activities in the national exam of high school. National exams in high school (SMA / SMK / MA / MAK) are considered important for several reasons, namely: a) national examinations encourage the improvement of education quality in schools; b) the national exam is an entry point to improve the quality of human resources and the competitiveness of the nation; (c) the national examination is an instrument for equalizing the quality of education; and (d) a description of the national education quality standard (Tjalla, 2015).

National Exam (Ujian Nasional, commonly abbreviated as UN or USBN) is a standard evaluation system of primary and secondary education in Indonesia and the equation of quality of education levels among the areas that are conducted by the Center for Educational Assessment, The Department of Education. The Law of the Republic of Indonesia number 20 of 2003 states that, in order to control the quality of education nationwide to be evaluated as a form of accountability of education providers to the parties concerned. Further stated that the evaluations conducted by independent agencies on a regular basis, comprehensively, transparently, and systematically to assess the achievement of national education standards and the monitoring process evaluation should be done continuously. Evaluation of the monitoring process is carried out continuously and continuous in the end will be able to fix the quality of education. Improving the quality of education begins with the determination of the standard. Determination standards continue to rise is expected to encourage increased quality of education, which is the determination of educational standards is the determination of the limit value (cut-off score). One is said to have passed the exam when it has passed the limit value of the boundary between learners who have mastered certain competencies with learners who have not mastered certain competencies. When that happens on the national exam or school then the boundary value function to separate the students who graduated and did not pass is called the limit of graduation, graduation delimitation activities called standard setting. Benefits of standard setting final exam:

- The limit of graduation each subject in accordance with the demands of minimum competency.

- The same standards for each subject as a minimum standard of competency achievement.

It has been proposed to do a computerized version of National Exam, with trials starting in 2015.

In the same year, National Exam is no longer a standard of education completion as it is stated on "PP NO 13 Tahun 2015".The government policy states that education completion will depend on completing all school learning programs, obtaining at least good on attitude aspect score, and passing the school exam. There is no cut-off score because the newest exam policy is aimed to map Indonesian students' competency in every single region in Indonesia. The data are going to be analyzed and will be used to make education improvement strategies in Indonesia.

The efficient readers understand the goal of reading and are able to form the reading style and the consequent. They have reasons to read and how to get to their goal of reading. Reading comprehension skill is important for students. The lack of reading comprehension skill means flawed readers. The main goal of reading is to gain information from the sources. In order to get it, the readers need to use many reading strategies. Reading strategies are ways to help the readers manage the information they read (Ahmadi et al., 2013). Reading strategies show how somebody gets easier to study and develop the work, especially students who try hard to understand the written context. Some strategies that can be used are skimming, scanning, skipping and flash technique (Ronkova \& Moldova, 2016) as well as work recognizing, one minute reading, survey, question, read, recite and review (SQ3R), survey, question, read, recite, relate and review (SQ4R).

\section{METHODS}

Quantitative research based on descriptive correlational design was used in this study, i.e. to assess the relationship between national examination score Indonesian Languange in high school (X1), reading strategies (X2) and students' reading comprehension skill (Y). The instruments used were scale reading strategies, scale reading Frequencies and reading comprehension test. The population of this study was 4996 student and 370 of them were taken as the sample by using proportional stratified random sampling technique. The data were attained in Universitas Negeri Padang through the following procedures: (a) preparing questionnaires for reading strategies and reading frequencies and a reading comprehension test; (b) providing the explanation about the questionnaire and how to fill them; (c) distributing the instruments and inviting students to fill them; and (d) collecting the data. Data were analyzed using descriptive statistic simple regression and multiple regressions analyses.

\section{FINDING AND DISCUSSION}

\section{Findings}

Before conducting the data analysis process, it needs to conduct the normality test where the results are as follows: 
Table 1. Test results normality

\begin{tabular}{ccccccc}
\hline & \multicolumn{2}{c}{ Kolmogorov-Smirnov $^{\mathrm{a}}$} & \multicolumn{3}{c}{ Shapiro-Wilk } \\
\cline { 2 - 7 } & Statistic & $\mathrm{df}$ & Sig. & Statistic & df & Sig. \\
\hline $\mathrm{X} 1$ & 0.108 & 353 & $0.200^{*}$ & 0.966 & 353 & 0.163 \\
\hline $\mathrm{Y}$ & 0.116 & 353 & 0.088 & 0.974 & 353 & 0.334 \\
\hline $\mathrm{X} 2$ & 0.083 & 353 & $0.200^{*}$ & 0.984 & 353 & 0.714 \\
\hline
\end{tabular}

*. This is a lower bound of the true significance.

a. Lilliefors Significance Correction

After normality test conducted, it shows that the data normally distributed. Then, the test simple regression and multiple regressions were carried out as follows:

Table 2. Model Summary

\begin{tabular}{cccccc}
\hline Model & $\mathrm{R}$ & R Square & $\begin{array}{c}\text { Adjusted R } \\
\text { Square }\end{array}$ & Std. Error of the Estimate & Sign \\
\hline 1 & $0.021^{\mathrm{a}}$ & 0.000 & -0.002 & 7.81958 & 0.693 \\
\hline 2 & $0.557^{\mathrm{b}}$ & 0.310 & 0.308 & 6.49568 & 0.000 \\
\hline 3 & $0.431^{\mathrm{c}}$ & 0.186 & 0.182 & 7.90992 & 0.000 \\
\hline
\end{tabular}

a. Predictors: (Constant), X1

b. Predictors: (Constant), X2

c. Predictors: (Constant), X1 and X2

The test of hypothesis was to examine the contribution of national examination score Indonesian Languange in high school and reading strategies toward students' reading comprehension skill. In the first step, the the contribution of national examination score Indonesian Languange in high school toward students' reading comprehension skill. The RSquare value is the degree of variation of the dependent variable, which can be predicted by the independent variable. Consequently, the analysis revealed national examination score Indonesian Languange in high school explained $0 \%$ variance in students' reading comprehension skill $(R 2=0.000)$. From this results in the table is statistically no significant $(\mathrm{Sig}=0.693)$. In the second step, the analysis showed that reading strategies was able to predict $31 \%$ variance in students' reading comprehension skill $(R 2=0.310)$. From this results in the table is statistically significant $(\mathrm{Sig}=0.000)$. In the third step, the analysis showed that national examination score Indonesian Languange in high school and reading strategies were able to predict $18.6 \%$ variance in students' reading comprehension skill $(R 2=$ $0.186)$. From this results in the table is statistically significant $(\mathrm{Sig}=0.000)$.

\section{Discussion}

The regression analysis result showed there was not the significant relationship between national examination score Indonesian Languange in high school to students' reading comprehension skill. There was obtained based on a series of data analysis showed that the contribution of the national examination score Indonesian Languange in high school to the students' reading comprehension skills is $0 \%$. That was, the value of national examination score Indonesian Languange in high school was not one of the factors that contribute to the reading comprehension skills of students or in other words the value of national examination score Indonesian Languange in high school could not predict the high level of students reading comprehension skills. The data that research get that the grid of subjects Indonesian High School to be tested only covers $20 \%$ of the material about reading comprehension, while other materials related to complete the sentence, terms, proverbs, effective sentences, standard sentence / unstandard sentences, and use of spelling in written and spoken language (BNSP, 2017).

The regression analysis result showed there was the significant relationship between reading strategies to students' reading comprehension skill. The good reading strategies will contribute to attaining the information (Sadeghi, Afghari, and Zarei, 2016). Reading strategies help students to manage and evaluate the ideas which are planned, deliberated, directed, and mentally future-oriented in order to complete the cognitive task (Chen, 2014). Moreover, reading strategies can be used to be a goal of cognitive activity used to establish and maintain the reading (Cakici, 2016). Besides that, reading strategies are also useful for improving the reading comprehension of the readers (Salataki, 2002). Reading strategies help students to understand the text well. Strategies are conscious and thoughtful activity. In using the strategies, the researcher emphasized of reading process itself to help understand the content. Previous studies pointed out that mastery reading strategies often help students to understand the text better, for students who have difficulties in paying attention or focusing on something (Marzban, 2013). The research findings of Zafarani and Kabgani (2014) also showed that the use of various strategies in reading gave a meaningful contribution to 
understanding the text. It is in line with Mokhtari \& Sheorey (2002) who stated that effective reading strategies will accomplish a better understanding of reading. Another finding was from Mujiselaar and De Jong (2014) showed that the predictors of reading strategies are able to improve reading comprehension.

\section{CONCLUSION AND RECOMMENDATION}

Based on research findings and discussion, there are several conclusions to take, as the following: (1) The national examination score Indonesian Languange in high school no contributed significance and positively to the students' comprehension reading skill which is $0 \%(\mathrm{R} 2=0.000$ and the significance of 0.693$)$. (2) The reading strategies contributed significance toward the students' reading comprehension skills of $33.1 \%$ (RR2 = 0.331 , and the significance of 0.000). That was, reading frequencies contributed directly to reading comprehension skills. Therefore, the better the reading frequencies, the better the reading comprehension skills of the students; (3) The national examination score Indonesian Languange in high school reading strategies together contributed significance toward the students' reading comprehension skills of $33.2 \%(\mathrm{R} 2=0.186$, and the significance of 0.000$)$. That was, the national examination score Indonesian Languange in high school and reading strategies together contributed directly to the comprehension reading skill. Therefore, the higher the reading strategies will be the better the reading comprehension skill of the students.

According to the research findings, discussion and conclusion, there are some suggestions to consider: (a) to the lecturers and Language Center to keep improving students' reading comprehension skills by providing the students special program about reading comprehension; (b) to languange lectures, lecturers can make reading as an initial activity in every meet in the classroom. Lecturers with students must prepare a short read material in accordance with the context of his age and course materials taken from various sources. This could improve the the reading strategies and reading strategies that contribute to the level of reading comprehension skill. (c) to the Rectors of Higher Education to support the lecturers and Language Center to provide the program to improve students' reading comprehension in Higher Education.

\section{References}

Abdellah, A.S. (2009). Eye vs Text movement; Which technique leads to faster reading comprehension. CDELT Occasional Papers, 48, 1-27.

Ahmadi, M. R., Ismail, H. N., Kamarul, M., \& Abdullah, K. (2013). The importance of metacognitive reading strategy awareness in reading comprehension, English language teaching, 6, 235-244.

Central Bureau of Statistics. (2012). Socio-Cultural Indicators. http://www.bps.go.id/webbeta/frontend/index.php/Subjek/view/27\#subjekViewTab3.

Botsas, G. (2017). Differences in strategy use in the reading comprehension of narrative and Science texts among students with and without learning disabilities. Contemporary Journal, 15, 139-162.

Cakici, D. (2016). Teachers ' beliefs about the use of reading strategies. Journal Of Language and Linguistic Studies, 12, 183-194.

Castillo, A. I., \& Bonilla, S. J. (2014). Building up autonomy through reading strategies. Profile, 16, 67-85.

Chen, J., (2014). Reading strategies employed by University Business English Majors with Different Levels of Reading Proficiency. English Language Teaching, 7, 25-37.

Ditzel, S. N. (2010). Metacognitive reading strategies can improve self-regulation. Journal of College Reading and Learning, 40, 45-63.

Duke, N. K., \& Pearson, P. D. (2002). Effective Practices for Developing Reading Comprehension. International Reading Association, 205-242.

Huang, H. (2014). Online versus paper-based instruction: Comparing two strategy training Modules for improving reading comprehension. RELC Journal, 45, 165 - 180.

Kasimi, Y. (2010). "Cognitive and metacognitive strategies employed by Iranian and Turkish EFL learners" (Unpublished doctoral dissertation). (Online) Hacettepe University, Ankara, Turkey.

Kendeou, P., Mcmaster, K. L., \& Christ, T. J. (2016). "Reading Comprehension : Core Components and Processes". https://doi.org/10.1177/237273221 5624707.

Koda, K. (2005). Insights into second language reading: A cross-linguistic approach. Cambridge: Cambridge University Press.

Macalister, J. (2010). Speed reading courses and their effect on reading authentic texts : A preliminary investigation. Reading in a Foreign Language, 22, 104-116.

Marzban, A., \& Akbarnejad, A. A. (2013). The effect of cooperative reading strategies on Improving reading comprehension of Iranian University Students. Procedia - Social and Behavioral Sciences, 70, 936-942.

Meniado, J. C. (2016). Metacognitive reading strategies, motivation, and reading comprehension performance of Saudi EFL Students. 9: 117-129. https://doi.org/10.5539/elt.v9n3p117. 
Mokhtari, K., \& Sheorey, R. (2002). “Measuring ESL students' awareness of reading strategies”. Journal of Development Education, 25, 2-10.

Papatga, E., \& Ersoy, A. (2016). Improving reading comprehension skills through the SCRATCH Program". International Electronic Journal of Elementary Education, 9, 124-150.

PISA. (2015). Survey International PISA. http://litbang.kemdikbud.go.id/index.php/survei internasional- PISA,

Rayner, K., Schotter, E. R., Masson, M. E. J., Potter, M. C., \& Treiman, R. (2016). So much to Read, so little time : How do we read, and can speed reading help. Psychological Science in the Public Interest, 17, 4-34.

Sadeghi, E., Afghari, A., \& Zarei, G. (2016). Shadow-reading effect on reading comprehension: Actualization of interactive reading comprehension : (A Vygotskyan View!). English Language Teaching, 9, 130-138.

Savage, R. (2017). Linguistic and reading comprehension in simultaneous dual language Instruction : Evidence against unitary constructs. International Journal of Bilingualism, 5, 1-20.

Seraye, A. M. (2016). Short vowels versus word familiarity in the reading comprehension of Arab Readers: A Revisited. International Electronic Journal of Elementary Education, 8, 81-506.

Solari, E. J., Grimm, R., McIntyre, N. S., Lerro, L. S., Zajic, M., \& Mundy, P. C. (2017). The relation between text reading fluency and reading comprehension for students with autism spectrum disorders. Research in Autism Spectrum Disorders, 41, 8-19.

Tjalla, Awaluddin. UN dan peningkatan mutu pembelajaran di sekolah. http://pustaka. ut.ac.id/pdfartikel/TIG602.pdf, diakses 30 Januari 2015.

Weiner, Harvey S. (1985). Reading skill hand book. Houghton Mifflin Co. USA.

Ulum, Ö. G. (2016). A descriptive content analysis of the extent of bloom's taxonomy in the reading comprehension questions of the course book q: Skills for success 4 reading and writing. The Qualitative Report, 21, 1674-1683.

Van Wingerden, E., Segers, E., Van Balkom, H., \& Verhoeven, L. (2017). Foundations of reading comprehension in children with intellectual disabilities. Research in Developmental Disabilities, 60, 211-222.

Wotschack, C., \& Kliegl, R. (2013). Reading strategy modulates parafoveal on foveal effects in Sentence reading. Quarterly Journal of Experimental Psychology, 66, 548-562.

Yildiz, M., \& Çetinkaya, E. (2017). The relationship between good readers ' attention, reading Fluency and reading comprehension. Universal Journal of Educational Research, 5, 366-371.

Yussof, Y.M., Jamian, A.R., Hamzah, Z.A.Z., Roslan, A. (2013). Students' reading comprehension performance with emotional. International Journal of Education and Literacy Studies, 1, 82-88.

Zafarani, P., \& Kabgani, S. (2014). Summarization strategy training and reading comprehension of Iranian ESP Learners. Procedia - Social and Behavioral Sciences, 98, 1959-1965.

Zsigmond, I. (2015). Writing strategies for fostering reading comprehension. ProcediaSocial and Behavioral Sciences, 180, 1698-1703. 